\title{
The Role of E-Business Adoption in Improving MSME Performance in Parepare City
}

\author{
Anis Anshari Mas'ud ${ }^{\mathrm{a}, *}$, Nurfadhilah $^{\mathrm{b}}$, Bakhtiar Tijjang $^{\mathrm{c}}$, Rustan Ali $^{\mathrm{c}}$ \\ ${ }^{a}$ Dipa Makassar University, Indonesia \\ ${ }^{b}$ Institut Agama Islam Negeri Parepare, Indonesia \\ ${ }^{c}$ Andi Sapada Institute of Social, Indonesia
}

\begin{abstract}
The purpose of this research is to look into and analyze the effects of integrated information systems, technical innovation, and e-business adoption on MSMEs in the manufacturing sector in Parepare City. A questionnaire was issued to 71 business actors using the purposive sample methodology as the data gathering method. Business owners and marketing services make up as many as 103 samples in the population. The results demonstrated that the integrated information system and technological innovation had a favorable and significant impact on enhancing the performance of MSMEs in Parepare City through the adoption of ebusiness when the data was examined using a structural equation model (SEM). The usage of e-business as an intervening variable improves the performance of MSMEs in a favorable and significant way. The findings of this study are expected to contribute to the advancement of management research and have an impact on MSME actors, particularly MSMEs in Parepare City, both trading and manufacturing, by increasing the ability to implement e-business in business processes, which will encourage MSMEs to adapt to information systems that integrate and innovate new technologies. This study employs a technological, organizational, and environmental (TOE) theoretical model. The theory in this study supports and proves the elements that can influence the use of e-business in terms of technology, organization, and environment.
\end{abstract}

Keywords: information systems integration, technological innovation, e-business, the performance of SMEs

\section{INTRODUCTION}

Good company management is an important thing to consider when starting a competitive firm. It is required by businesses in order to meet the expectations of the business environment. Because it adopts a management system that is based on the demands of the business environment, the company will be able to compete and develop well. The current state of the corporate environment necessitates the development of a strong strategy for dealing with rapid environmental changes and commercial competitiveness. The advancement of science and technology has an impact on corporate development; in this scenario, integration is critical in supporting a company's activities. MSME performance cannot be measured solely in terms of financial performance; it must be balanced with non-financial measurements.

Micro, small, and medium enterprises (MSMEs) were thought to be more resilient than large businesses at the start of the financial crisis. When compared to notable entrepreneurs, MSMEs

*Author in correspondence,

Email address: anisanshari177@gmail.com (Anis Anshari Mas’ud)

ISSN: 2549-3221 (Print) 2549-323X (Online)

DOI: 10.26487 /hebr.v5i3.3403 can retain their performance, and it has been proved that large entrepreneurs, rather than MSMEs, are the source of many bad loans. MSMEs have a high level of resilience because their capital structure is based on their capital. According to Nuryanti (2013), MSMEs have a capital structure that comprises of $73 \%$ own capital, $4 \%$ private banks, $11 \%$ government banks, and 3\% suppliers. In Indonesia, all economic pillars are working together to achieve a mutually advantageous outcome, with MSMEs at the vanguard of the home economic activity.

The development of science and technology impacts business development; in this case, integration plays an essential role in supporting the activities of a company. MSME performance is not enough to measure performance in terms of finance alone but needs to be balanced with non-financial measurements. To make it easier to achieve the desired target, many companies compete to take advantage of technological sophistication by switching to electronic commerce. The term using the internet as a marketing medium can be called e-business, the business activity of goods and services carried out automatically through an electronic system using a computer or smartphone.

MSMEs were considered more resilient at the beginning of the monetary crisis-era than large entrepreneurs. MSMEs can 
maintain their performance compared to prominent entrepreneurs, and it is proven that large entrepreneurs, rather than MSMEs cause many bad loans. The resilience of MSMEs is strong because their capital structure depends on their capital. Nuryanti (2013) said that the capital structure of MSMEs consists of $73 \%$ own capital, $4 \%$ private banks, $11 \%$ government banks, and $3 \%$ suppliers. All economic pillars in Indonesia are sought not to run separately but with a mutually beneficial cooperation pattern where MSMEs are at the forefront of the domestic economic movement.

The potential of MSMEs in driving the economy must be considered, and MSMEs are required to make changes and innovations using an integrated information system to increase competitiveness, one of which is by utilizing e-commerce. In addition to integrated information systems, e-commerce also plays an essential role in supporting the performance of MSMEs; turning an integrated information system into a capability can be a crucial business to achieve the desired goals (Saty et al., 2018). Still, if MSMEs in the manufacturing sector do not turn an integrated information system into a capability, it will be in vain because it will not provide benefits to the performance of the MSME.

Micro, small and medium enterprises in the City of Parepare also determine the structure of the local economy. The development of MSME Sales in Parepare City contributed to economic growth in 2018 of $6.98 \%$, and employment increased from 147,391 in 2014 to 183,430 in 2020 (Bappeda, 2020). This is relevant to research Sutikno et al. (2016) that MSMEs are a factor in creating economic value in the structure of the national economy. The support of business information systems indirectly determines the high performance of MSMEs in Parepare City. Strategy formulation for MSME development is determined by complete, accurate, and timely information. Suci (2017) said that the main weakness of MSMEs in making decisions is due to the lack of relevant information. So important is information in the development of MSMEs, so Sarfiah et al. (2019) say that the development of MSME performance must be supported by quality information to help improve its performance.

MSMEs in Parepare City can take more advanced steps of change by collecting data from internet services. MSMEs are the traditional model for emerging prominent entrepreneurs, creating jobs, and contributing to the country's economy. Based on the explanation, this research refers to the Technology Organization Environment Theory (TOE). The TOE theory introduced by Tornatzky and Fleischer (1990) is a theory that is often used to introduce new technologies in analyzing factors on technology, organization, and environmental factors. The only use of e-business in MSMEs. Technological factors include integrated information systems, which are information systems that involve various functional units or interrelationships between sub-systems both within and outside the company. The use of information systems plays an essential role in supporting the process of using e-business.

\section{LITERATURE REVIEW}

The research conducted by Chatzoglou et al. (2017) also refers to the TOE theory, which according to this approach, a company's decision to introduce new technology is influenced by technological, organizational, and environmental factors. Using several variables such as competitive pressure, benefits of e-commerce, technological capabilities, and barriers to the use of e-commerce, using Structural Equation Model (SEM) data analysis techniques.

The results show that competitive pressures and perceived benefits positively affect e-commerce use, while technological barriers have a negative effect on e-commerce u se. In addition, the use of e-commerce has a positive effect on company performance. The difference between this study and research Chatzoglou et al. (2017) lies in the variables, objects, and analytical tools used. This study uses the e-commerce variable as a moderating variable while the research by Caruso and Marchiori (2003) uses the e-business variable as an intervening variable; the object of this research focuses on SMEs in the service and trade sector while the object focuses on manufacturing company.

In addition to the differences from previous studies, the uniqueness of this research is that there are still few studies, especially in Indonesia, that examine e-commerce, especially in the MSME sector. The impact of increasingly sophisticated technology affects small and medium-sized businesses because it affects consumer buying patterns. In addition, there is a difference (Research Gap) in previous studies related to e-commerce objects and variables. Therefore researchers want to investigate further the Role of E-Business Adoption in Micro, Small, and Medium Enterprises in Parepare City.

\section{RESEARCH METHODS}

\subsection{Research Model}

This research is explanatory research that explains the influence between several variables by testing hypotheses. The unit of analysis of this research is micro, small, and medium enterprises (MSMEs) which is the object of research in the MSME sector engaged in manufacturing in the City of Parepare. Data was collected using the primary data collection method by giving questionnaires to respondents in the form of a survey (selfadministered survey).

\subsection{Population and Sample}

The population in this study is the MSME sector which is engaged in manufacturing. The sampling technique was purposive sampling. Purposive sampling is a technique for taking samples by setting specific criteria. The criteria in this research are SMEs in the manufacturing sector located in Parepare City; SMEs that include their address on Google Maps also have a website. 


\subsection{Method of collecting data}

This study uses a questionnaire method using a questionnaire (questionnaire), which is a data collection technique carried out by giving written questions to respondents, and these questions will be answered based on the Likert scale technique. The questionnaire distributed in a structured manner contains a list of questions addressed to respondents to obtain information related to each variable of integrated information systems, technological innovation, e-business adoption, and MSME performance.

\subsection{Data Analysis}

The analysis in this study uses descriptive statistics, which are intended to determine the frequency distribution of answers from the questionnaire results. They tabulated in tables and carried out illustrative discussions by collecting data from the effects of respondents' answers. The descriptive measure provides numbers, both in the number of respondents and the average value of solutions and percentages. Data analysis is used to describe the effect of integrated information systems, networking, and technological innovation on the performance of MSMEs through the adoption of e-business.

\section{RESULT AND DISCUSSION}

\subsection{Data analysis}

Respondents in this study were business owners, employees, and the marketing department. Questionnaires were distributed in person and online using Google Drive to respondents. The number of questionnaires distributed was 103 questionnaires. A total of 71 copies of the questionnaire were returned and filled out in full, meaning that the return of the questionnaire that did not return was 32 copies; the reason for not returning was because some MSME respondents were not operating due to the COVID-19 pandemic, some were on holiday, and some had the wrong address. In the analysis of the research model used, 103 questionnaires were used.

Table 1: Distribution of questionnaire

\begin{tabular}{clc}
\hline No. & Criteria & $\begin{array}{c}\text { Number } \\
\text { of Years }\end{array}$ \\
\hline 1 & $\begin{array}{l}\text { Number of Manufacturing MSMEs lo- } \\
\text { cated in the city of Parepare }\end{array}$ & 103 \\
2 & $\begin{array}{l}\text { MSMEs that are not operating during } \\
\text { the COVID-19 pandemic }\end{array}$ & 8 \\
3 & $\begin{array}{l}\text { MSMEs that do not include a website } \\
\text { address }\end{array}$ & -24 \\
& $\begin{array}{l}\text { Number of Respondents of manufac- } \\
\text { turing MSMEs in Parepare Kota }\end{array}$ & 71 \\
\hline Source: Processed secondary data, 2021 & \\
\hline
\end{tabular}

Characteristics of respondents for gender indicate that the number of male respondents is less than that of female respondents. In this study, the number of female respondents was 72 people, or $70.1 \%$ of the total respondents, while male respondents were 31 people or $29.9 \%$ of the total respondents.

Analysis of the measurement model (outer model) aims to measure the validity and reliability of the model through the algorithm process in SEM analysis with the Analysis of Moment Structure (AMOS) program. This measurement model (outer model) includes validity tests (convergent validity and discriminative validity). As a predictive model that does not use a specific distribution to estimate parameters and predict causality relationships. Based on the framework of the analytical model, the reformulation (reduce form) used in this study is:

$$
\begin{aligned}
& Y_{1}=f\left(X_{1}, X_{2}\right) \\
& Y_{2}=f\left(X_{1}, X_{2}, Y_{1}\right)
\end{aligned}
$$

Simultaneous equation systems can be formed estimation equations. The estimation equations based on the reduced form are as follows.

$$
\begin{gathered}
Y_{1}=f\left(X_{1}, X_{2}\right) \\
=\alpha_{0}+\alpha_{1} X_{1}+\alpha_{2} X_{2}+\epsilon_{1} \\
Y_{2}=f\left(X_{1}, X_{2}, Y_{1}\right) \\
=\beta_{0}+\beta_{1} X_{1}+\beta_{2} X_{2}+\beta_{3} Y_{1}+\epsilon_{2}
\end{gathered}
$$

Substitute equation (2) into equation (3):

$$
\begin{aligned}
Y_{2} & =f\left(X_{1}, X_{2}, Y_{1}\right) \\
Y_{2} & =\beta_{0}+\beta_{1} X_{1}+\beta_{2} X_{2}+\beta_{3}\left(\alpha_{0}+\alpha_{1} X_{1}+\alpha_{2} X_{2}+\epsilon_{1}\right)+\epsilon_{2} \\
& =\beta_{0}+\beta_{1} X_{1}+\beta_{2} X_{2}+\alpha_{0} \beta_{3}+\alpha_{1} \beta_{3} X_{1}+\alpha_{2} \beta_{3} X_{2}+\epsilon_{1} \beta_{3}+\epsilon_{2} \\
Y_{2} & =\left(\beta_{0}+\alpha_{0} \beta_{3}\right)+\left(\alpha_{1} \beta_{3}\right) X_{1}+\alpha_{2} \beta_{3} X_{2}+\left(\epsilon_{1} \beta_{3}+\epsilon_{2}\right)
\end{aligned}
$$

Information:

$X_{1}$ : information systems integration;

$X_{2}$ : technological innovation;

$Y_{1}$ : adopt e-Business;

$Y_{2}:$ performance of SMEs;

$\alpha$ : a constant;

$\beta_{1}:$ regression coeficient;

$\epsilon_{i}:$ standard error.

The Structural Equation Modeling (SEM) is used as an analytical tool to test and analyze a hypothetical model that proves the effect of exogenous variables on endogenous variables is the purpose of this study. The advantages of SEM are that it can be used to test variables together (1) structural model, on the relationship between independent and dependent constructs, (2) measurement model, relationship (loading value) between indicators and constructs (latent variable).

\subsection{Validity Test}

Validity testing uses construct validity or factorial validity. Convergent validity relates to the principle that the indicators (manifest variable) of a variable should be highly correlated. The validity test can be seen from the loading factor for each construct indicator. 
Table 2: Questionnaire distribution returns

\begin{tabular}{clc}
\hline No & Description & Amount \\
\hline 1 & Distributed Questionnaire & 103 \\
2 & Questionnaire not filled & 32 \\
& Number of Questionnaires processed & 71 \\
\hline
\end{tabular}

Source: Processed secondary data, 2021

\subsection{Reliability testing}

The data is said to be reliable if the instrument used several times to measure the same data will produce the same object as well. In the reliability test carried out using the standard Cronbach's Alpha $>0.50$ it can be said that the research data is considered quite reliable. From the results of the analysis of the research data, it can be obtained from the reliability value test that the overall construct of this study has a Cronbach's Alpha value greater than 0.50 , it can be concluded that all variables in this research instrument are said to be reliable.

\subsection{Hypothesis Testing}

From the empirical model proposed in this study, the hypothesis has been tested by testing the path coefficient on the structural equation model. Path coefficient test on the influence of intervening variables or indirect variables in the research objective hypothesis can be accepted or rejected to answer the proposed hypothesis. In intervening or indirect variables in this study, it is intended that a variable is called intervening if the variable can affect the relationship between each dependent variable and the independent variable. In the mediation of hypothesis testing, this research was developed by Sobel (1982) with the procedure tested using Sobel test; Sobel testing was carried out using a way of trying the strength through the intervening variable $(\mathrm{Y})$ on the variable $(\mathrm{X})$ namely the relationship of indirect or independent influence (X) and the dependent variable (Z) (Ghozali, Imam, 2017).

The first hypothesis testing is an integrated information system on the performance of MSMEs through the adoption of ebusiness, as shown in the Table 5.

The test Table 5 got a p-value of 0.004 which is $<5 \%$, proving that the use of e-business on the relationship of integrated information system variables can mediate the performance of MSMEs. So, it can be concluded that $\mathrm{H} 1$ is acceptable.

Testing the second hypothesis, namely the influence of technological innovation on the performance of MSMEs through the use of e-business is shown in the Table 6 .

The Table 6 gets a p-value of 0.00 which is $<5 \%$; it is proven that the use of e-business on technological innovation and MSME performance can be mediated. So, it can be concluded that $\mathrm{H} 2$ is accepted.

Testing the third hypothesis, namely the direct influence of e-business adoption on the performance of MSMEs, can be seen in the Table 7. In the Table 7, it is known that there is a significant and positive influence between e-business adoption and MSME performance. This is indicated by the estimated value of 0.398 , which indicates that there is a positive relationship, the
SE value is 0.138 , and the $\mathrm{P}$-value is $0.004<0.05$, which indicates that there is a significant influence between the variables of e-business adoption and MSME performance at the probability level. Five percent. So, it can be concluded that H3 is accepted.

\subsection{Discussion}

The discussion of the results of this study was carried out in analyzing the findings obtained from observations in micro, small and medium enterprises in the City of Parepare. Where can the findings of this study empirically be obtained:

Integrated Information System has a positive and significant impact on the performance of MSMEs through the adoption of EBusiness.

The results of this study are relevant to the results of research conducted by previous researchers, such as research conducted by Anshari and Payangan (2020) and Neneh (2018) (which concluded that integrated information systems have a significant and positive influence on the level of e-commerce use and are part of The most important thing in supporting the maximum and effective e-commerce adoption process will have an impact on the performance of MSMEs themselves. So to achieve maximum performance in the adoption of e-commerce, it is necessary to use an integrated and maximum information system, especially in MSME business activities.

The integrated information system in this study is the level of connectivity between information systems involving various business functional units and those integrated externally by improving company performance, reducing operational costs, saving time, and improving customer service (Caruso and Marchiori, 2003). Integrated information systems are very important in the use of e-business because the adoption of e-business requires an efficient flow of data along the value chain and must automatically communicate changes in every transaction made so that it is always in sync with the data owned by the company with the systems and databases of business partners or business client.

The positive influence between integrated information systems and company performance through the use of e-commerce is also supported by the TOE (Technology organization environment) theory. According to TOE theory, the company's decision to encourage the adoption or use of new technology is influenced by technological, environmental, and organizational factors. One of the technological factors includes an integrated information system. An integrated information system for micro, small and medium enterprises is essential because it is the main factor for the success or failure of the use of e-business.

After all, the use of e-business requires an efficient flow of sales data along the company's value chain, especially the MSME sector. The company's integrated information system is essential because it is the main factor in the success or failure of the use of e-business. After all, the use of e-business requires efficient data flow along the company's value chain, especially the MSME sector. Therefore, MSME business activities with the ability to apply more sophisticated information 
Table 3: Validity Test

\begin{tabular}{|c|c|c|c|c|}
\hline $\begin{array}{l}\text { Variable } \\
\text { Type }\end{array}$ & Construct & Statement & $\begin{array}{l}\text { Corrected } \\
\text { Item }\end{array}$ & Description \\
\hline \multirow{4}{*}{ Exogen } & \multirow{4}{*}{ Information systems integration } & $\mathrm{X} 1.1$ & 0.68 & Valid \\
\hline & & $\mathrm{X} 1.2$ & 0.738 & Valid \\
\hline & & $\mathrm{X} 1.4$ & 0.751 & Valid \\
\hline & & $\mathrm{X} 1.5$ & 0.53 & Valid \\
\hline \multirow{5}{*}{ Exogen } & \multirow{5}{*}{ Technological innovation } & $\mathrm{X} 2.1$ & 0.481 & Not Valid \\
\hline & & $\mathrm{X} 2.2$ & 0.677 & Valid \\
\hline & & $\mathrm{X} 2.3$ & 0.571 & Valid \\
\hline & & $\mathrm{X} 2.4$ & 0.532 & Valid \\
\hline & & $\mathrm{X} 2.5$ & 0.365 & Not Valid \\
\hline \multirow{6}{*}{ Endogen (Intervening) } & \multirow{6}{*}{ Adopt e-business } & Y1 & 0.55 & Valid \\
\hline & & $\mathrm{Y} 2$ & 0.343 & Not Valid \\
\hline & & Y1.3 & 0.228 & Not Valid \\
\hline & & Y1.4 & 0.657 & Valid \\
\hline & & Y1.5 & 0.672 & Valid \\
\hline & & Y1.6 & 0.672 & Valid \\
\hline \multirow{6}{*}{ Endogen (depends) } & \multirow{6}{*}{ Performance of SMEs } & Y2.1 & 0.584 & Valid \\
\hline & & $\mathrm{Y} 2.2$ & 0.66 & Valid \\
\hline & & $\mathrm{Y} 2.3$ & 0.766 & Valid \\
\hline & & Y2.4 & 0.729 & Valid \\
\hline & & Y2.5 & 0.547 & Valid \\
\hline & & Y2.6 & 0.636 & Valid \\
\hline
\end{tabular}

Source: Processed secondary data, 2021 
Table 4: Reliability testing

\begin{tabular}{llcl}
\hline $\begin{array}{l}\text { Variable } \\
\text { type }\end{array}$ & Construct & $\begin{array}{l}\text { Alpha Cron- } \\
\text { bach's }\end{array}$ & Reliability \\
\hline \multirow{5}{*}{ Exogen } & $\begin{array}{l}\text { Information sys- } \\
\text { tems integration }\end{array}$ & 0.835 & Realible \\
& $\begin{array}{l}\text { Technological inno- } \\
\text { vation }\end{array}$ & 0.754 & Realible \\
& $\begin{array}{l}\text { Adopt E-Business } \\
\text { Endogen }\end{array}$ & 0.772 & Realible \\
& $\begin{array}{l}\text { Performance of } \\
\text { SMEs }\end{array}$ & 0.858 & Realible \\
\hline
\end{tabular}

Source: Processed secondary data, 2021

technology will integrate and use their information resources; this affects the company's performance in terms of improving product quality and customer service (Chatzoglou et al., 2017).

\section{Technological Innovations Have a Positive and Significant Im- pact on MSME Performance Through E-Business Adoption.}

This study found that the variable of technological innovation or innovation has a significant and positive effect on the performance of MSMEs on e-business adoption. This means that the second hypothesis, which states that technological innovation affects MSME performance through e-business adoption, can be tested empirically so that it can be accepted. The results of this test indicate that the adoption of e-business in micro, small and medium enterprises is supported because the application of innovation in the organization changes each time stage by taking better and different actions than before. This process will strengthen the performance of MSMEs but must be supported by the use of technology, so innovation is strongly influenced by foresight, creativity, changes in the business environment.

Most respondents tend to feel that the adoption of e-business in the performance of MSMEs, especially in the manufacturing sector, is influenced by an innovation process that will create the phenomenon of networking (internet-working) as a step in determining position in the market, forcing companies to reform by adopting various information about market changes to be able to provide competitive products and services. So innovation is a tool to give a chance to increase market share.

The intensity of innovation is an important driver of the use of technology as research Laudon and Traver (2016) suggests that innovation is the act or process of introducing something new such as e-business adoption, so innovation is a tool to provide change to increase market share. The significant influence between technological innovation and MSME performance through e-business is also supported by the TOE theory (Technology Organization Environment Theory) by Hoti (2015). Various empirical studies such as those conducted (Donbesuur et al., 2020), which prioritizee technological innovation in the form of new ideas or ways to carry out technological updates in the form of technology development using TOE theory, agree with Tornatzky and Fleischer (1990) that the three TOE contexts are as follows: technology, organization, and environment influence the adoption and use of technology.
Bagheri et al. (2019) show that technological innovation has a positive effect on the use of e-business, there is a positive relationship between the use of e-business on the performance of MSMEs. Internet use is primarily for marketing/advertising purposes, exchanging information with customers, and selling online, but not for purchasing. This proves that MSMEs are using e-business adoption intending to attract and strengthen market share, which is an important strategy to face market competition.

E-Business Adoption has a positive and significant effect on MSME performance

The results of this study found that the variable use of ebusiness has a positive and significant effect on the performance of MSMEs. This influence can be seen from the estimated value, which positively impacts e-business adoption and MSME performance. This shows that the third hypothesis, which states that the adoption of e-business has a positive and significant effect on the performance of MSMEs, can be tested empirically so that it can be accepted. The adoption of e-business in this study is the use of information technology using the web to facilitate online product and service sales transactions as well as a tool to buy and sell products or services by using a computer system via the internet network to improve the overall efficiency of the company's services. MSME performance is the final result or achievement of a company that can be measured by measurements in terms of financial (income growth, return on investment, and market share) and non-financial (consumer satisfaction, consumer increase, and customer loyalty). It consists of trade that occurs through consumers visiting the business unit's website and online transactions. The results of this study are in line with research conducted (Migdadi et al., 2016) supported by research (Popa et al., 2018), showing that the scope of ebusiness adoption has a positive impact on MSME performance in terms of improving internal processes, competition, service delivery.

Customers, and overall MSME performance. When e-business is implemented correctly and optimally, it will provide positive benefits to the company's performance both financially and non-financially, such as increased sales, customer satisfaction, and business development. In addition, information technology (IT) plays an important role in supporting e-business processes in the MSME business sector. The success rate of ebusiness depends on the level of MSMEs' ability to change their technology into capabilities in the business sector. The significant influence between the use of e-business and business performance is supported by the TOE theory (Technology Organization Environment Theory) with the ability of an organization to use information resources in adopting increasingly sophisticated technology so that Information technology (IT) plays an essential role in supporting the process of using e-business. Therefore, the business sector's level of use of e-business depends on integrated information systems and technological innovations used in MSME activities. Therefore MSMEs with higher information technology capabilities will be able to integrate and use their information resources; this 
Table 5: Integrated Information System Testing

\begin{tabular}{lllrrr}
\hline \multirow{2}{*}{ Code } & \multirow{2}{*}{ Variable } & \multirow{2}{*}{ Variable } & \multicolumn{3}{c}{ Direct Effect } \\
\cline { 3 - 6 } & & & Standardized & S.E & P-Value \\
\hline H1 & Adopt E-Business (Y1) & Information systems integration (X1) & 0.27 & 0.06 & 0 \\
\hline \multicolumn{2}{l}{ Performance of SMEs (Y2) } & Adopt E-Business (Y1) & 0.398 & 0.14 & 0.004 \\
\hline Source: Processed secondary data, 2021
\end{tabular}

Table 6: Testing Technological Innovations

\begin{tabular}{lllccc}
\hline \multirow{2}{*}{ Code } & \multirow{2}{*}{ Variable } & \multirow{2}{*}{ Variable } & \multicolumn{3}{c}{ Direct Effect } \\
\cline { 3 - 6 } & & & Standardized & S.E & P-Value \\
\hline H2 & Adopt E-Business (Y1) & Technological innovation (X2) & 0.227 & 0.05 & 0 \\
\hline \multicolumn{2}{c}{ Performance of SMEs (Y2) } & Adopt E-Business (Y1) & 0.398 & 0.14 & 0.004 \\
\hline Source: Processed secondary data, 2021 & & & &
\end{tabular}

Table 7: Testing the Use of E-Business on MSME Performance

\begin{tabular}{cccccc}
\hline \multirow{2}{*}{ Code } & \multirow{2}{*}{ Variable } & Variable & \multicolumn{3}{c}{ Direct Effect } \\
\cline { 3 - 6 } & & Standardized & S.E & P-Value \\
\hline H3 & Performance of SMEs (Y2) & Adopt E-Business (Y1) & 0.398 & 0.14 & 0.004 \\
\hline Source: & Processed secondary data, 2021 & & &
\end{tabular}

influences MSME performance in terms of product sales and marketing (Melović et al., 2020).

\section{CONCLUSION}

Based on the findings of this study, the adoption of e-business as the digitalization of the company, which is the key to business processes in the use of information technology (IT), which can play a role, can be used to improve the performance of MSMEs, particularly in the manufacturing sector. This is critical in supporting e-business operations in MSME sector business activities, as e-business success is determined by the MSME's capacity to transform the technology they have into commercial power. MSMEs in Parepare City, particularly those in the manufacturing industry, require an efficient data flow along the value chain and must automatically communicate changes to every transaction so that they are always in sync with the company's data and the system and database of business partners/ clients. They were aided by an integrated business information system that is precise in the connectivity relationship between information systems and technological innovations, resulting in a networking phenomenon (internetworking) that will determine market position and force MSMEs to make changes in terms of sales and marketing.

\section{References}

Anshari, A., Payangan, O. R., 2020. Factors Determinant of E-Commerce and Impacts on Increasing Company Performance. Global Scientific Journal 8 (6), 2111-2123.
Bagheri, M., Mitchelmore, S., Bamiatzi, V., Nikolopoulos, K., 2019. Internationalization Orientation in SMEs: The Mediating Role of Technological Innovation. Journal of International Management 25 (1), 121-139. URL: https://doi.org/10.1016/j.intman.2018.08.002

Bappeda, S., 2020. BAPPEDA Sulsel 2020.

Caruso, A., Marchiori, M., 2003. The Adoption of Information Systems in SMEs : Organizational Issues and Success Factors. ECIS 2003, 393-398. URL: http://20030092.pdf

Chatzoglou, P., Chatzoudes, D., Fragidis, L., Symeonidis, S., 2017. Examining the critical success factors for erp implementation: An explanatory study conducted in SMEs. Lecture Notes in Business Information Processing 277, 179-201.

URL: https://doi.org/10.1007/978-3-319-53076-5\{_\}10

Ghozali, Imam, 2017. Aplikasi Analisis Multivariate dengan Program IBM SPSS 21. Badan Penerbit Universitas Diponegoro.

Hoti, E., 2015. The technological, organizational and environmental framework of IS innovation adaption in small and medium enterprises. Evidence from research over the last $10,1-14$.

URL: https://doi .org/10.20472/bm. 2015.3.4.001

Laudon, K. C., Traver, C. G., 2016. E-Commerce 2016: Business, Technology, Society, Global Edition, 12th Edition, global Edición. Pearson.

URL:https://www. pearson. com/uk/educators/

higher-education-educators/program/

Laudon-E-Commerce-2016-Business-Technology-Society-Global -Edition-PGM1092762.html

Melović, B., Jocović, M., Dabić, M., Vulić, T. B., Dudic, B., 2020. The impact of digital transformation and digital marketing on the brand promotion, positioning and electronic business in Montenegro. Technology in Society 63 (10142), 5.

URL: https://doi.org/10.1016/j.techsoc. 2020.101425

Neneh, B. N., 2018. Customer orientation and SME performance: the role of networking ties. African Journal of Economic and Management Studies 9 (2), 178-196.

URL: https ://doi.org/10.1108/AJEMS-03-2017-0043

Nuryanti, 2013. Peran E-Commerce Untuk Meningkatkan Daya Saing Usaha Kecil dan Menengah ( UKM ). Jurnal Ekonomi Manajemen Ekonomi Universitas Riau 21 (4), 15. 
Sarfiah, S., Atmaja, H., Verawati, D., 2019. UMKM Sebagai Pilar Membangun Ekonomi Bangsa. Jurnal REP (Riset Ekonomi Pembangunan) 4 (2), 1-189. URL: https://doi .org/10.31002/rep.v4i2.1952

Saty, F. M., Apriyani, M., Supriyatna, A. R., 2018. Persepsi Pelaku UMKM Terhadap Penerapan e-Bisnis Pertanian di Bandar Lampung. Prosiding Seminar Nasional Pengembangan Teknologi Pertanian, 1-7.

URL: https://jurnal.polinela.ac.id/PROSIDING/article/ view/1133

Sobel, M. E., 1982. Asymptotic Confidence Intervals for Indirect Effects in Structural Equation Models. Sociological Methodology 13, 290-321.
Suci, Y. R., 2017. Perkembangan UMKM (Usaha Mikro Kecil Menengah) di Indonesia. Vol. 6. Jurnal Ilmiah Fakultas Ekonomi.

URL: https://e-journal.upp.ac.id/index.php/Cano/article/ view/1239

Sutikno, Satriyo Adhy, Endah, S. N., 2016. Penerapan E-Commerence untuk Meningkatkan dan Memperluas Pemasaran di UMKM (Studi Kasus di UMKM Pengrajin Tahu Putih dan Telur Asin di Kabupaten Klaten). Jurnal Ekonomi Manajemen Akuntansi 23 (40), 1-15.

Tornatzky, L., Fleischer, M., 1990. The process of technology innovation. Lexington Books, Lexington, MA. 